\title{
Studi Perbandingan Jaringan Optik Eksisting dengan Gigabit Passive Optical Network (GPON) di Kampus Universitas Udayana Bukit Jimbaran
}

\author{
I Putu Yuda Pramana Putra ${ }^{1}$, Pande Ketut Sudiarta ${ }^{2}$, Gede Sukadarmika ${ }^{3}$ \\ $1,2,3$ Jurusan Teknik Elektro, Fakultas Teknik, Universitas Udayana \\ Email: yudapramana96@gmail.com ${ }^{1}$, sudiarta@unud.ac.id $^{2}$, sukadarmika@ee.unud.ac.id $^{3}$
}

\begin{abstract}
Abstrak
Tujuan penelitian ini adalah membandingkan kondisi jaringan optik eksisting yang menggunakan teknologi point to point dengan jaringan GPON yang dirancang untuk wilayah kampus Universitas Udayana Bukit Jimbaran Bali. Jaringan optik saat mempunyai kemampuan melayani 14 gedung dari 77 gedung produktif yang ada karena jumlah core yang terbatas. Untuk memenuhi komunikasi ke semua gedung diperlukan core yang sangat banyak. Pada penelitian ini ditawarkan sebuah metode yang menggunakan teknologi Gigabit Passive Optical Network (GPON). Langkah awal pada penelitian ini adalah melakukan analisa kondisi jaringan eksisting, selanjutnya dilakukan perancangan jaringan GPON. Parameter yang dibandingkan adalah Link Power Budget, Rise Time Budget dan Bit Error Rate serta dilakukan perbandingan penggunaan core, jumlah pengguna serta estimasi perangkat dan biaya transmisi. Berdasarkan penelitian yang dilakukan, untuk memenuhi komunikasi optik ke semua gedung yang ada penggunaan jaringan GPON hanya menggunakan 22 core, jika dibandingkan dengan model jaringan eksisting yang menggunakan 154 core. Penggunaan jaringan GPON dapat menurunkan kualitas jaringan dibandingkan jaringan eksisting. Namun jika diterapkan untuk banyak gedung jaringan GPON lebih sederhana dan ekonomis.
\end{abstract}

Kata kunci: Bit Error Rate, GPON, Link Power Budget, Optisystem, Rise Time Budget

\section{Abstract}

The purpose of this study is to compare the existing optical network conditions that use point to point technology with GPON network designed for Udayana University campuses area in Bukit Jimbaran Bali. The Existing optical network is currently able to serve only 14 buildings from 77 existing productive buildings due to the limited number of available optical cores.. It means in order to connect each building at the campuses area, it is required much more optical fiber. Alternatively is using Gigabit Passive Optical Network (GPON) technology. This research was conducted by analyzing the condition of the existing optical network and designing the GPON network. Here are compared some network feasibility parameters ie Link Power Budget, Rise Time Budget and Bit Error Rate. Then compare the use of cores, the number of subscribers as well as device estimation and transmission costs. The study found that to connect all of the buildings are GPON configuration required only 22 optical cores, compared to 154 cores for eksisting network designs. However, the GPON design has lower network quality but is simpler and much more economical if it is implemented for a wide network.

Keywords: Bit Error Rate, GPON, Link Power Budget, Optisystem, Rise Time Budget

\section{PENDAHULUAN}

Universitas Udayana (UNUD) adalah perguruan tinggi tertua yang berada di Provinsi Bali, Indonesia berdiri pada tanggal 17 Agustus 1962 [1]. Jumlah mahasiswa Universitas Udayana pada tahun 2015 adalah 19.366 mahasiswa dengan 1.648 dosen [2]. Universitas Udayana memiliki 13 fakultas dengan 112 jurusan yang berada di tiga lokasi berbeda. Kampus Bukit Jimbaran merupakan kampus terbesar dari tiga kampus di Universitas Udayana [3].

Seiring dengan pengembangan ilmu pengetahuan, pembangunan dan teknologi menyebabkan meningkatnya 
kebutuhan akan data dan layanan akses yang cepat, handal dan efisien, baik dari segi kualitas maupun kuantitas [4][5]. Serat optik merupakan media yang banyak digunakan saat ini karena memiliki bandwidth yang bisa mengakomodasi kebutuhan tersebut [6] [7].

Di kampus Universitas Udayana Bukit Jimbaran sudah menggunakan media serat optik. Namun jaringan tersebut masih menggunakan arsitektur jaringan fiber optik poin to point serta terbatas menghubungkan data sentral ke gedung-gedung yang melayani administrasi kemahasiswaan karena jumlah core yang terbatas. Salah satu solusi yang dapat diterapkan untuk memenuhi komunikasi optik ke seluruh gedung yang ada adalah menggunakan tekonogi Gigabit Pasive Optical Network (GPON).

GPON adalah salah satu jaringan akses fiber optik yang distandarisasi oleh ITU-T G.984 [8]. Teknologi ini dapat membagi bandwidth menjadi 32 sampai 128 ONT dan mengurangi penggunaan kabel dibandingakan point to point [9] [10]. Jaringan GPON memiliki arsitekturnya lebih sederhana dan dapat menghemat energi yang cukup besar karena menggunakan komponen pasif [8] [11].

Untuk mengetahui perbandingan dari kedua teknologi tersebut, maka dilakukan simulasi jaringan eksisting dan simulasi jaringan GPON yang dirancang. Simulasi akan dibuat pada aplikasi Optisystem. Aplikasi ini dapat digunakan dalam perancangan jaringan optik dengan output yang ditampilkan berupa total daya yang diterima dan Bit Error Rate (BER) [12].

Dari hasil simulasi akan dicari parameter kelakayan jaringan yaitu link power budget, rise time budget dan BER dari jaringan eksisting maupun dari jaringan GPON yang dirancang. Kemudian dilakukan perbandingan dari kedua jaringan tersebut dengan membandingkan parameter kelayakan jaringan, penggunaan core, jumlah yang dilayani, serta penggunaan perangkat dan estimasi biaya dari masing-masing jaringan tersebut.

\section{KAJIAN PUSTAKA}

\subsection{Serat Optik}

Serat optik adalah sebuah media transmisi fisik yang terbuat dari kaca dilapisi isolator sebagai pelindung berguna untuk menyalurkan informasi berupa gelombang cahaya. Serat optik mempunyai bentuk yang halus dan memiliki ketebalan hingga $1 \mathrm{~mm}$ untuk dua puluh helai serat. Selain ringan, kapasitas kanal dari serat ini sangat besar. Struktur serat optic, ditunjukkan pada Gambar 1, ada 3 yaitu core, cladding dan coating [13].

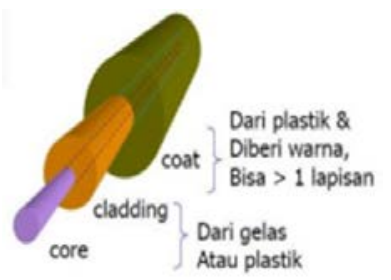

Gambar 1. Struktur Kabel Serat Optik [13]

\subsection{Aktive Optical Network (AON)}

AON adalah jaringan akses yang menggunakan serat optik dan kabel tembaga konvensional serta menggunakan perangkat aktif untuk membagi penggunaan media serat optik. Implementasi dari AON lebih dikenal sebagai Active Node, penggunaan teknologi ini terbatas karena biayanya yang sangat tinggi. Peralatan aktif yang digunakan AON termasuk optical Switch, yang memerlukan sumber atau tenaga listrik. Salah satu standardisasi dari jaringan AON point to poin adalah ITU-T G.986 yaitu 1 Gbit/s point-topoint Ethernet-based optical access system dengan sistem komunikasi yang ditunjukkan pada Gambar 2. 


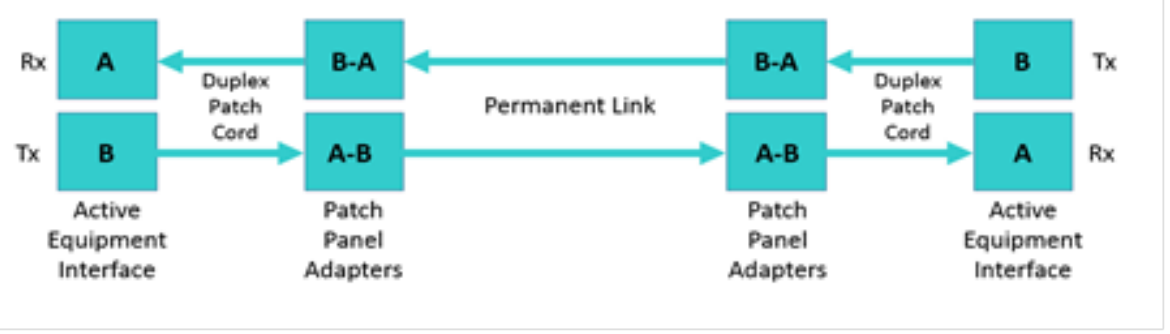

Gambar 2. Komunikasi AON Point to Point

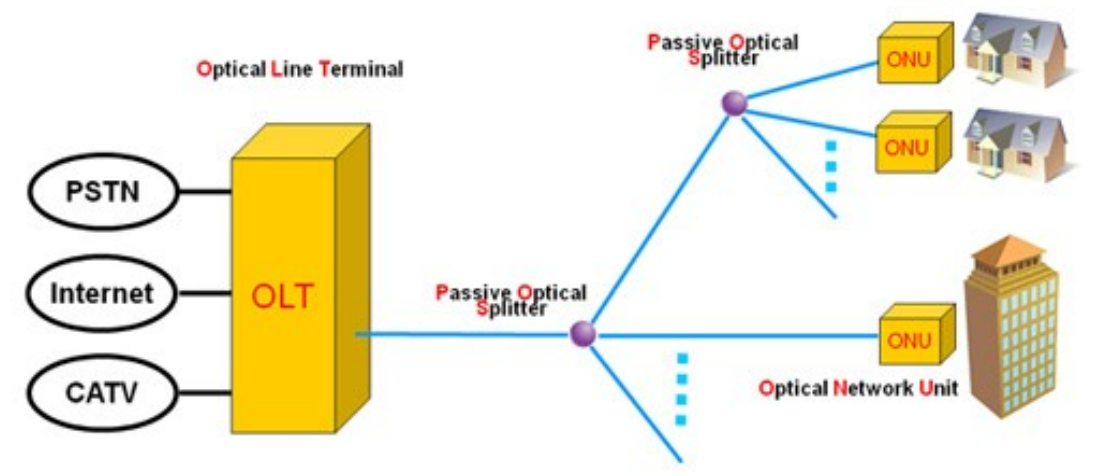

Gambar 3. Struktur Jaringan GPON

\subsection{Gigabit Passive Optical Network (GPON)}

GPON adalah teknologi jaringan akses lokal fiber optik berbasis PON yang distandardisasi oleh ITU-T (ITUT G.984 series). Secara umum Struktur jaringan GPON ditunjukkan pada Gambar 3. Pada GPON, sebuah atau beberapa OLT, interface sentral dengan jaringan fiber optik, dihubungkan dengan beberapa ONU, interface pelanggan dengan jaringan serat optik, menggunakan pasif Optical Distribution Network (ODN), seperti splitter, filter, atau perangkat pasif optik lainnya. GPON mampu memberikan layanan dengan kecepatan 2.4 Gbps secara simetris (upstream dan downstream) atau 2.4 Gbps untuk downstream dan $1.2 \mathrm{Gbps}$ untuk upstream [4].

\subsection{Link Power Budget}

Perhitungan link power budget untuk mengetahui batasan redaman total yang diijinkan antara daya keluaran pemancar dan sensitivitas penerima. Perhitungan ini dilakukan berdasarkan standarisasi ITU-T G.984 dan juga peraturan yang diterapkan oleh PT. Telkom, yaitu jarak tidak lebih dari $20 \mathrm{~km}$ dan redaman total tidak lebih dari $28 \mathrm{~dB}$ atau $\mathrm{Pr}=-28 \mathrm{dBm}$ dengan margin daya tidak boleh lebih besar dari 0. Bentuk Persamaan untuk menentukan link power budget adalah sebagai berikut.

$$
M=\left(P_{\mathrm{t}}+P_{r}\right)-\alpha_{\text {tot }}-S M
$$

Keterangan :

$\mathrm{P} \_\mathrm{t}=$ Daya keluaran dari sumber optik (dBm)

$P \_r=$ Sensitivitas daya maksimum detector $(\mathrm{dBm})$

$\mathrm{SM}=$ Safety margin, berkisar 6-8 $\mathrm{dB}$

a_tot $=$ Redaman total sistem (dB)

\subsection{Rise Time Budget}

Rise time budget merupakan metode untuk menentukan batasan dispersi suatu link serat optik. Metode 
ini sangat berguna untuk menganalisa sistem transmisi digital. Tujuan dari metode ini adalah untuk menganalisa apakah unjuk kerja jaringan secara keseluruhan telah tercapai dan mampu memenuhi kapasitas kanal yang diinginkan. Umumnya degradasi total waktu transisi dari link digital tidak melebihi $70 \%$ dari satu periode bit NRZ (Non-retum-to-zero) atau 35 persen dari satu periode bit untuk data RZ (return-to-zero). Satu periode bit didefinisikan sebagai resiprokal dari data rate. Untuk menghitung rise time budget dapat dihitung dengan (2).

$$
t_{s}=\left(t_{\text {tx }}^{2}+t_{\text {intra }}^{2}+t_{\text {intey }}^{2}+t_{v x}^{2}\right)^{1 / 2}(2)
$$

Keterangan :

$$
\begin{array}{ll}
\mathrm{t} \_\mathrm{tx} & =\text { Rise time transmitter }(\mathrm{ns}) \\
\mathrm{t} \_\mathrm{rx} & =\text { Rise time receiver }(\mathrm{ns}) \\
\mathrm{t} \text { intra } & =\text { bernilai nol (untuk serat optik } \\
& \text { single mode) } \\
\mathrm{t} \text { inter } & =\mathrm{t} \text { material }+\mathrm{t} \text { _waveguide } \\
\mathrm{t} \text { material } \quad=\Delta \sigma \times \mathrm{L} \times \mathrm{Dm} \\
\overline{\Delta \sigma} \quad=\text { Lebar spektral }(\mathrm{nm}) \\
\mathrm{L} \quad=\text { Panjang serat optik }(\mathrm{km})
\end{array}
$$

$\mathrm{Dm}=$ Dispersi material $(\mathrm{ps} / \mathrm{nm} \cdot \mathrm{km})$

\subsection{Bit Error Rate}

Bit error rate merupakan laju kesalahan bit yang terjadi dalam mentransmisikan sinyal digital. Sensitivitas merupakan daya optik minimum dari sinyal yang datang pada bit error rate yang dibutuhkan. Menurut standar ITU-T G.984.2 BER maksimum untuk sistem komunikasi optik sebesar 10-9. Maksud dari penulisan 10-9 adalah terdapat kemungkinan 1 bit yang error dari 109 data yang dikirimkan dalam 1 kali proses transmisi. Semakin kecil nilai bit error rate maka semakin baik kondisi suatu jaringan telekomunikasi. BER dapat dihitung dengan menggunakan Persamaan (3).

$$
B E R=\frac{1}{2} \operatorname{erfcc}\left(\frac{Q}{\sqrt{2}}\right)
$$

Dengan nilai Q atau Q-faktor minimal yang bagus dalam komunikasi optik adalah 6 [15].

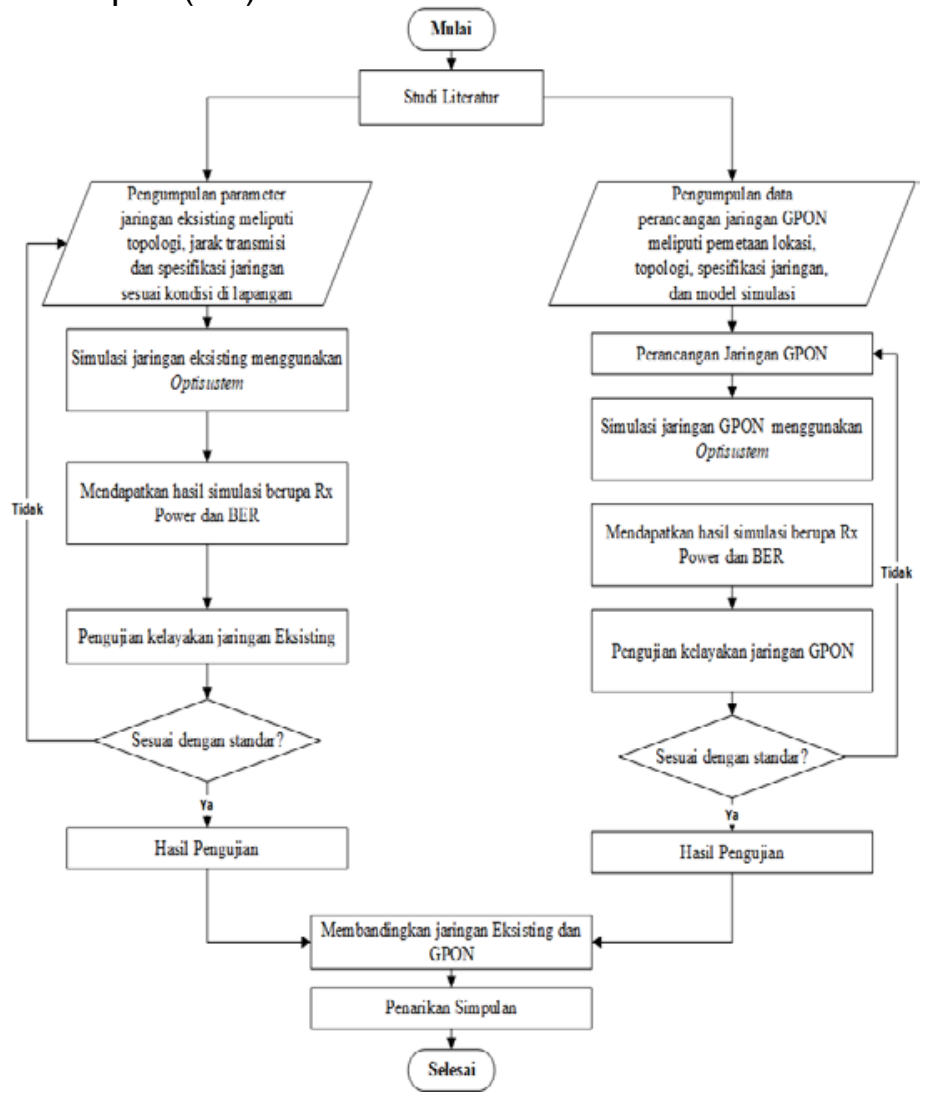


Gambar 4. Diagram alir Penelitian

\section{METODE PERANCANGAN}

Penelitian perancangan ini dilakukan di Kampus Universitas Udayana yang berada di wilayah Bukit Jimbaran. Alur dari penelitian ini dilakukan dengan beberapa tahapan yang ditunjukkan pada Gambar 4.

Analisa kondisi jaringan eksisting akan ditampilkan gambaran dari jaringan optik yang ada saat ini di Kampus Universitas Udayana Bukit Jimbaran baik dari topologi, jarak dan spesifikasi perangkat. Kemudian dilakukan simulasi menggunakan aplikasi optisystem untuk memperoleh nilai kelayakan jaringan optik meliputi link power budget, rise time budget, dan BER serta penggunaan core dan jumlah pengguna yang dilayani.

Jaringan GPON yang dirancang adalah wilayah kampus Universitas Udayana Bukit Jimbaran, sedangkan yang digunakan sebagai referensi adalah jaringan yang sudah ada saat ini untuk dikembangkan. Hasil rancangan ini selanjutnya dianalisa. Lokasi jaringan ditentukan menggunakan aplikasi Google Earth, yaitu posisi penyedia layanan dan penerima layanan serta untuk menghubungkannya. Sehingga jarak setiap transmisi yang didesain bisa diketahui. Selanjutnya dilakukan studi untuk menentukan spesifikasi perangkat yang digunakan pada transmisi GPON berdasarkan standar ITU-T. Selanjutnya akan dilakukan simulasi pada aplikasi optisystem untuk menentukan kelayakan jaringan yang dirancang yang berupa link power budget, rise time budget, dan BER serta kebutuhan core dan jumlah pelanggan yang dilayani.

Hasil analisa kondisi jaringan eksisting dengan hasil perancangan dan Analisa jaringan GPON akan dibandingkan. Perbandingan dilakukan berdasarkan kelayakan jaringan yang dihasilkan, jumlah core yang digunakan, jumlah pelanggan yang dilayani dan kebutuhan perangkat dari setiap transmisi. Sehingga hasil perancangan dapat digunakan sebagai refrensi untuk pengembangan jaringan optik yang ada di wilayah kampus Universitas Udayana Bukit Jimbaran dari jaringan yang sudah ada.

\section{HASIL DAN PEMBAHASAN}

\subsection{Hasil}

\subsubsection{Jaringan Eksisting}

Jaringan Kampus Universitas Udayana Bukit Jimbaran saat ini sudah menggunakan media serat optik. Namun belum semua Gedung mendapatkan transmisi optik karena keterbatasan jumlah core dan komunikasi yang digunakan adalah poin to point.

1. Topologi Jaringan Topologi dari jaringan eksisting ditunjukkan oleh Gaqmbar 5.

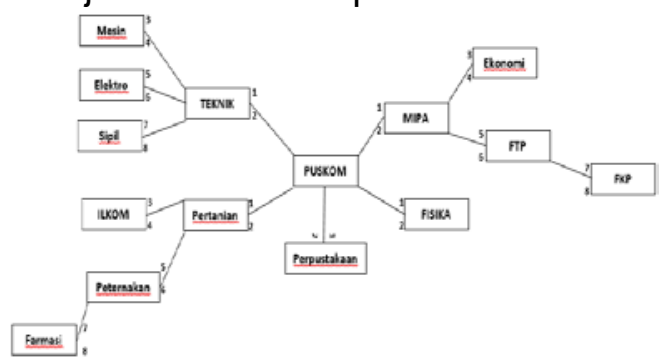

Gambar 5. Topologi Jaringan Eksisting

Karena sistem komunikasi optik yang digunakan adalah komunikasi point to point, maka transmisi datanya menggunakan dua buah core untuk melakukan komunikasi ke satu titik yang dituju, satu core digunakan untuk transmitter (tx) dan core yang kedua digunakan sebagai receiver ( $\mathrm{rx}$ ). Karena djumlah gedung yang dilayani adalah 14, jumlah core yang dugunakan dan ditarik ke puskom adalah sebanyak 28 buah. Sedangkan jumlah gedung yang ada adalah 77 . Jarak dari transmisi ke setiap gedung ditunjukkan pada Tabel 1. 
Tabel 1. Jarak Transmisi

\begin{tabular}{|l|l|}
\hline Penerima & Jarak (m) \\
\hline Perpustakaan & 90 \\
\hline Fisika & 105 \\
\hline Dekanat Mipa & 401 \\
\hline Ekonomi & 618 \\
\hline FTP & 618 \\
\hline FKP & 713 \\
\hline Dekanat Teknik & 625 \\
\hline Teknik Sipil & 384 \\
\hline Teknik Elektro & 711 \\
\hline Teknik Mesin & 772 \\
\hline Dekanat Pertanian & 1094 \\
\hline Ikom & 1237 \\
\hline Dekanat Perternakan & 1345 \\
\hline Farmasi & 1585 \\
\hline
\end{tabular}

\section{Konfigurasi Perangkat}

Jaringan serat optik eksisting menggunakan perangkat pengirim dan penerima yang sama yaitu TP-LINK MC210CS(UN) Ver.2.23 sejumlah 28 buah. Jenis kabel optik yang digunakan adalah kabel serat optik single mode G.625 dengan konektor SC (Subscriber Connector).
Spesifikasi lengkap dari jaringan eksisting dapat dilihat pada Tabel 2 .

Tabel 2. Konfigurasi Perangkat

\begin{tabular}{|l|c|}
\hline Format Modulasi & $\begin{array}{c}\text { NRZ (Non Return To } \\
\text { Zero) }\end{array}$ \\
\hline $\begin{array}{l}\text { Panjang Gelombang ( }(\boldsymbol{\lambda}) / \\
\text { Loss }\end{array}$ & $\begin{array}{c}\text { Single Mode } 1310 \mathrm{~nm} / \\
0.35 \mathrm{~dB} / \mathrm{km}\end{array}$ \\
\hline Bit Rate & $1000 \mathrm{Mbps}$ \\
\hline Rise Time Transmitter $\left(\mathrm{t}_{\mathrm{tx}}\right)$ & $0,2 \mathrm{~ns}$ \\
\hline Rise Time Receiver $\left(\mathrm{t}_{\mathrm{rx}}\right)$ & $0,15 \mathrm{~ns}$ \\
\hline Dispersi Kromatis $(\mathrm{D})$ & $4.3 \times 10^{-3} \mathrm{~ns} /(\mathrm{nm} . \mathrm{km})$ \\
\hline Lebar Spektral $\left(\sigma_{\mathrm{\lambda}}\right)$ & $0,1 \mathrm{~nm}$ \\
\hline Daya Transmitter $\left(\mathrm{P}_{\mathrm{t}}\right)$ & $4 \mathrm{~dB}$ \\
\hline Receiver Sensitifity $(\mathrm{Pr})$ & $-28 \mathrm{~dB}$ \\
\hline Redaman Konektor & $0,3 \mathrm{~dB}$ \\
\hline SM & $8 \mathrm{~dB}$ \\
\hline
\end{tabular}

3. Simulasi Pada Optisystem

Simulasi dilakukan pada aplikasi Optisystem 7.0 dengan konfigurasi jaringan sesuai Gambar 6 .

Gambar 6 menunjukkan model simulasi untuk 1 link jaringan point to point. Parameter yang dimasukan pada simulasi akan disesuaikan dengan konfigurasi jaringan dan jarak transmisi. Hasil simulasi yang didapatkan berupa daya yang diterima dan BER.

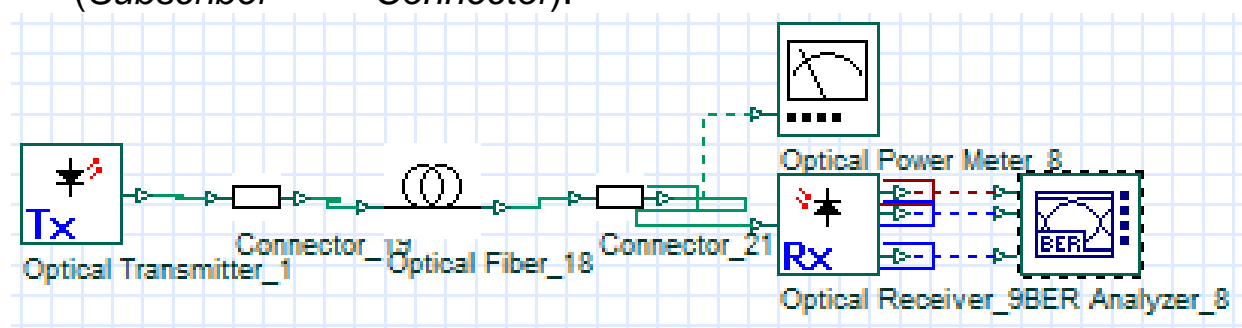

Gambar 6. Simulasi Pada Optisystem

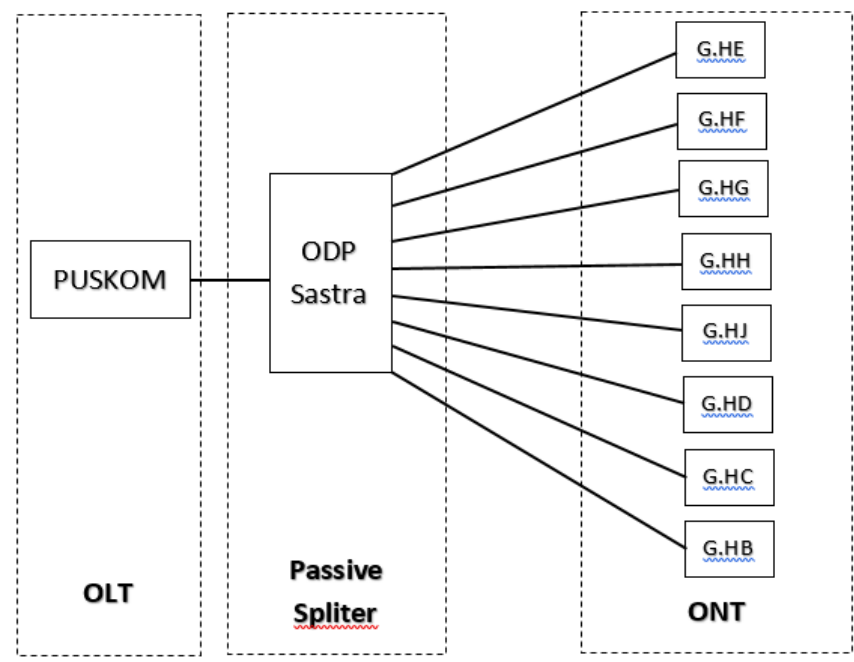


Gambar 7. Topologi GPON untuk ODP Sastra

\subsubsection{Perancangan Jaringan GPON}

Jaringan yang akan dibangun berupa jaringan FTTH berteknologi GPON. Jaringan ini akan menuju ke setiap gedung produktif yang ada di lingkungan kampus Universitas Udayana Bukit Jimbaran. Perancangan dilakukan dengan memetakan gedung yang ada melalui peta Google Earth dan pengamatan langsung ke lapangan.

1. Perancangan Topologi

Jaringan ini terdiri dari pusat transmisi atau Optical Line Terminal (OLT), ODP (Optical Distribution Point) yang di dalamnya terdapat Passive Splitter, Optical Network Terminal (ONT), serta kabel fiber optik yang menghubungkan jaringan tersebut. Salah satu topologi jaringan untuk ODP Sastra dapat dilihat pada Gambar 7.

Gambar 7 menunujkkan topologi jaringan GPON dari OLT sampai ke ONT pada satu ODP yaitu ODP Sastra. Terdapat 11 ODP dalam perancangan jaringan GPON di kampus Universitas Udayana Bukit Jimbaran dengan menggunakan model pada Gambar 7. Keseluruhan dari jaringan yang dirancang dapat dilihat pada Google Earth, yang ditunjukkan pada Gambar 8.

Gambar 8 merupakan desain seluruh jaringan GPON serta jarak setiap transmisinya. Terdapat 11 ODP untuk melayani semua gedung diantaranya ODP Sastra, ODP Ekonomi, ODP MIPA, ODP Rektorat 1, ODP Rektorat 2, ODP RS UNUD, ODP SIpil, ODP Teknik 1, ODP Teknik 2, ODP Pertanian, dan ODP Peternakan.

2. Konfigurasi Perangkat Konfigurasi terdiri dari beberapa perangkat yang digunakan yaitu OLT, ONT, Kabel Fiber Optik, Konektor, Sambungan dan Splitter. OLT (Tabel 3) dan ONT (Tabel 4) yang digunakan dalam perancangan ini sesuai dengan standar ITU-T G.984 dan yang di rekomendasikan oleh PT. Telkom.

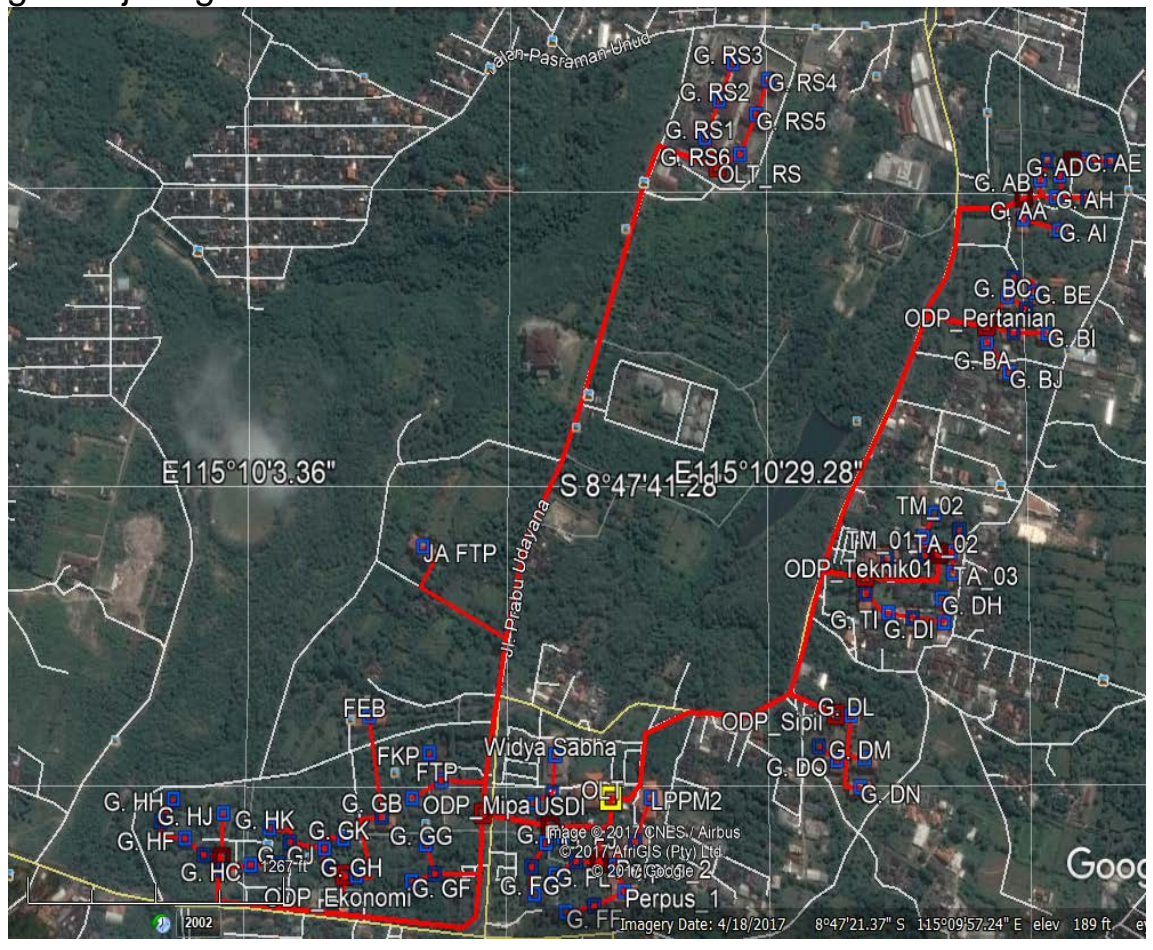


Gambar 8. Desain Keseluruahan Jaringan

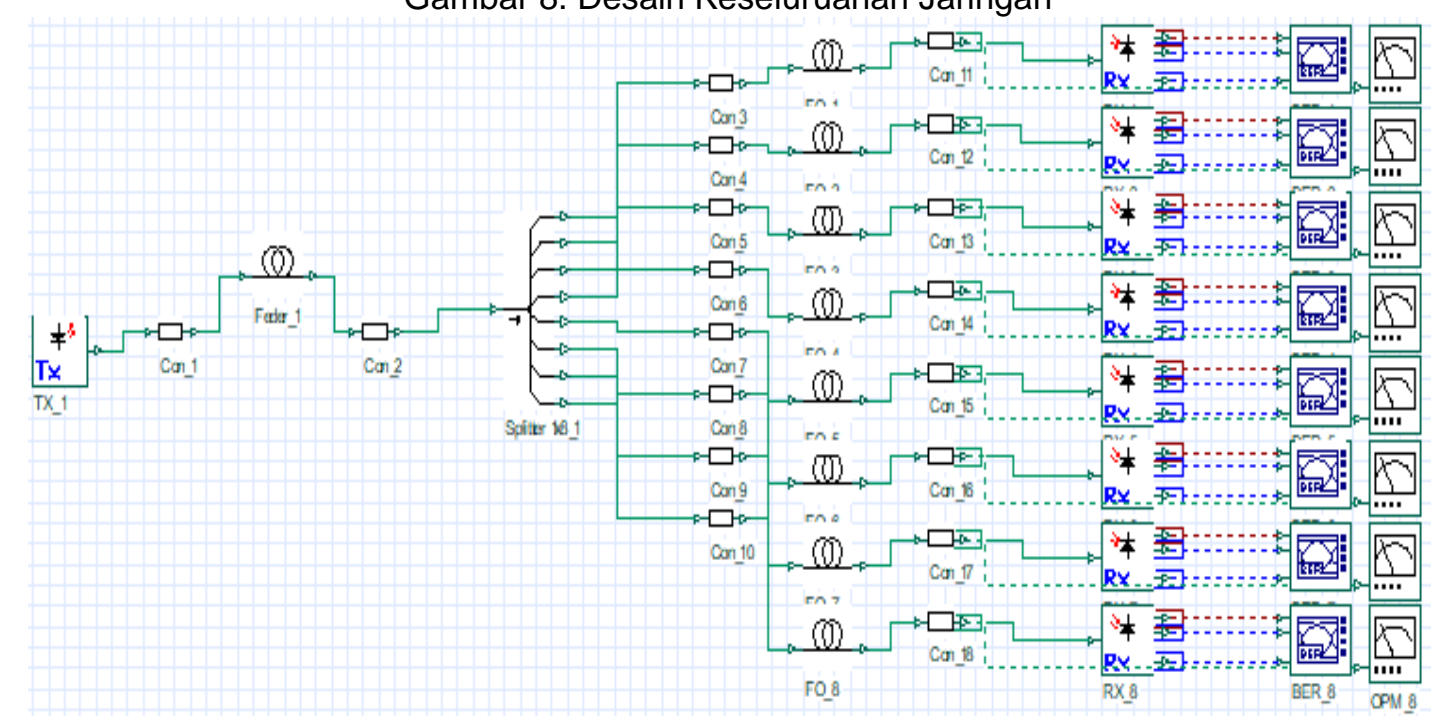

Gambar 9. Model SImulasi

Tabel 3. Spesifikasi OLT

\begin{tabular}{|c|c|c|}
\hline Parameter & Spesifikasi & Satuan \\
\hline $\begin{array}{c}\text { Optical Transmitter } \\
\text { Power }\end{array}$ & 5 & $\mathrm{dBm}$ \\
\hline Downlink Wavelenght & 1490 & $\mathrm{Nm}$ \\
\hline Spectrum Width & 1 & $\mathrm{Nm}$ \\
\hline Downstream Rate & 2,4 & $\mathrm{Gbps}$ \\
\hline Dispersi Kromatis (D) & $13.64 \times 10^{-3}$ & $\mathrm{ps} /(\mathrm{nm} . \mathrm{km})$ \\
\hline Optical Rise Time & 160 & $\mathrm{Ps}$ \\
\hline \\
\begin{tabular}{|c|c|c|}
\hline Tabel 4. Spesifikasi ONT & Satuan \\
\hline Parameter & Spesifikasi & $\mathrm{dBm}$ \\
\hline $\begin{array}{c}\text { Receive } \\
\text { Sensitifity }\end{array}$ & -28 & $\mathrm{Nm}$ \\
\hline $\begin{array}{c}\text { Spectrum Width } \\
\text { Dispersi } \\
\text { Kromatis (D) }\end{array}$ & 1 & $\mathrm{ps} /(\mathrm{nm} . \mathrm{km})$ \\
\hline $\begin{array}{c}\text { Optical Rise } \\
\text { Time }\end{array}$ & 200 & $\mathrm{Ps}$ \\
\hline
\end{tabular}
\end{tabular}

Serat optik yang digunakan adalah yang sesuai dengan standar ITU-T G.652.D dan G.657.A. Menggunakan konektor SC dan spliter 1:8 dengan loss spliter sebesar 10,5 $\mathrm{dB}$.

3. Simulasi Pada Optisystem Mekanisme pembuatan perancangan jaringan FTTH berteknologi GPON pada aplikasi Optisystem dilakukan dengan skema pada Gambar 9.

Gambar 9 menunjukkan konfigurasi jaringan GPON untuk satu ODP, yaitu satu core fiber optik akan melayani lebih dari satu ONT atau gedung. Hasil simulasi diukur dengan menggunakan Optical Power Meter dan BER Analizer pada aplikasi.

\subsection{Pembahasan}

\subsubsection{Analisa Jaringan Eksisting}

1. Kelayakan Jaringan Eksisting kelayakan jaringan merupakan nilai dari kualitas jaringan dalam melakukan komunikasi. Berikut contoh perhitungan dari link power budget dan rise time budget menggunakan persamaan (2) dan (4).

Link power budget dihitung dengan memasukan parameter simulasi dan redaman total simulasi dengan contoh sebagai berikut.

$$
\begin{aligned}
M \quad & =\left(P_{\mathrm{t}}+P_{r}\right)-\alpha_{\text {tot }}-S M \\
& =(4+28)-2,963-8 \\
& =17,037 \mathrm{~dB}
\end{aligned}
$$

Untuk perhitungan rise time budget dapat dilihat pada contoh berikut.

$$
\begin{aligned}
& t_{s}=\left(t_{t x}^{2}+t_{\text {intra }}{ }^{2}+t_{\text {inter }}{ }^{2}+t_{r x^{2}}\right)^{1 / 2} \\
& \text { Keterangan, } \\
& t_{\text {intra }}=0 \text { (fiber optik single mode) } \\
& t_{\text {inter }}= \\
& \Delta \sigma x L \times D m=0,1 \times 0,09 \times 0.0043= \\
& 0,0000387 \text { ns } \\
& t_{s}=\left(0,2^{2}+0^{2}+0.0000387^{2}+0.15^{2}\right)^{1 / 2} \\
& \quad=0,25 \mathrm{~ns}
\end{aligned}
$$


2. Kondisi Jaringan Eksisting

Dari data jaringan, hasil simulasi dan perhitungan kelayakan jaringan eksisting didapatkan nilai link power budget terkecil sebesar 16,514 dB serta nilai rise time budget sebesar 0,275 ns. Untuk nilai BER tertinggi sebesar $1.98 \times 10^{-117}$. Dari nilai kelayakan jaringan tersebut, jaringan eksisting masih sangat layak dibandingkan dengan standar. Sehingga jaringan eksisting ini sangat mungkin untuk dikembangkan ke jaringan yang dapat memberikan pemerataan jaringan optik untuk setiap gedung yang ada. Oleh sebab itu perlu dilakukan pengembangan jaringan yang ada ke jaringan yang relevan saat ini yaitu jaringan GPON.

\subsubsection{Analisa jaringan GPON}

Hasil simulasi dan kelayakan jaringan GPON dapat dilihat pada Tabel 5.

Tabel 5. Hasil kualitas jaringan GPON

\begin{tabular}{|c|c|c|}
\hline Parameter & Nilai Terendah & Nilai Tertinggi \\
\hline $\begin{array}{c}\text { Link Power } \\
\text { Budget }\end{array}$ & 12,04 & 12,404 \\
\hline $\begin{array}{c}\text { Rise Time } \\
\text { Budget }\end{array}$ & 0,28 & 0,28 \\
\hline BER & $4.36 \times 10^{-121}$ & $2.32 \times 10^{-102}$ \\
\hline
\end{tabular}

Tabel 5 menunjukkan bahwa perancangan jaringan GPON layak karena nilai kelayakan jaringannya memenuhi standar ITU-T, yaitu link power budget lebih dari 0 , rise time budget lebih rendah dari 0,7 ns dan BER lebih rendah dari $10^{-9}$.

\subsubsection{Perbandingan Jaringan Eksisting dan Jaringan GPON}

1. Perbandingan Penggunaan Core Analisa kondisi jaringan eksisting dan perancangan jaringan GPON ditunjukkan pada Tabel 6 .

Tabel 6. Perbandingan Penggunaan Core

\begin{tabular}{|c|c|c|c|c|c|}
\hline \multicolumn{2}{|c|}{$\begin{array}{l}\text { Jaringan } \\
\text { Eksisting }\end{array}$} & \multicolumn{2}{|c|}{$\begin{array}{c}100 \% \text { Gedung } \\
\text { Terlayani } \\
\text { Menggunakan } \\
\text { Model Point to } \\
\text { Point }\end{array}$} & $\begin{array}{c}\text { 100\% Gedung } \\
\text { Terlayani } \\
\text { Menggunakan } \\
\text { Model GPON }\end{array}$ \\
\hline Core & Dilayani & Core & Dilayani & Core & Dilayani \\
\hline
\end{tabular}

\begin{tabular}{|l|l|l|l|l|l|}
\hline 28 & $\begin{array}{l}14 \\
\text { gedung }\end{array}$ & 154 & $\begin{array}{l}77 \\
\text { gedung }\end{array}$ & 22 & $\begin{array}{l}77 \\
\text { gedung }\end{array}$ \\
\hline
\end{tabular}

Tabel 6 menunjukkan bahwa hanya 14 gedung yang dilayani jaringan optik dengan menggunakan 28 buah core. Jika dilakukan pemenuhan komunikasi optik ke seluruh gedung yang ada, dengan peningkatan pengguna yang cukup besar, model jaringan GPON lebih efektif diterapkan. Hal ini ditunjukkan bahwa dengan menggunakan 22 core sudah dapat memenuhi komunikasi ke seluruh gedung dibandingkan dengan menggunakan model point to point yang menggunakan 154 core.

\section{Perbandingan Kualitas Jaringan} Perbandingan kelayakan jaringan eksisting dengan hasil perancangan GPON mengggunakan nilai rata-rata dari hasil simulasi dan perhitungan. Nilai yang dibandingkan adalah link power budget, rise time budget, dan bit error rate (BER).

Tabel 7. Perbandingan Kualitas Jaringan

\begin{tabular}{|l|l|l|}
\hline $\begin{array}{l}\text { Link Power } \\
\text { Budget }\end{array}$ & Eksisting & $16,81 \mathrm{~dB}$ \\
\cline { 2 - 3 } $\begin{array}{l}\text { Rise Time } \\
\text { Budget }\end{array}$ & GPON & $12.24 \mathrm{~dB}$ \\
\hline \multirow{2}{*}{ BER } & Eksisting & $0,275 \mathrm{~ns}$ \\
\cline { 2 - 3 } & GPON & $0,28 \mathrm{~ns}$ \\
\cline { 2 - 3 } & Eksisting & $1,04 \times 10^{-11 /}$ \\
\hline
\end{tabular}

Dari Tabel 7 dapat dilihat perbandingan kelayakan jaringan dari jaringan Eksisting dan hasil perancangan GPON. Dapat dilihat bahwa kelayakan dari jaringan eksisting lebih baik dibandingkan jaringan GPON. Hal ini sesuai dengan teori yang ada, yaitu jaringan eksisting yang merupakan jaringan optik point to point merupakan jariungan yang paling ideal sedangkan pada jaringan GPON terdapat redaman dari penggunaan passive splitter.

\section{Perbandingan Kebutuhan Perangkat \\ Rstimasi biaya dari pegunaan perangkat diperoleeh dengan menggunakan referensi harga pada toko online maupun referensi yang}


ada, sebagai contoh Lazada.co.id, Tokopedia.com, Bukalapak.com, Fiberoptic.top, dan Bhinneka.com. Tabel 8 dan Tabel 9 merupakan penggunaan perangkat dan estimasi biaya jaringan eksisting dan jaringan GPON.

Tabel 8. Perangkat Jaringan Eksisting

\begin{tabular}{|c|l|c|c|}
\hline No & Nama Perangkat & Jumlah & Total Harga \\
\hline 1 & $\begin{array}{l}\text { TP-LINK } \\
\text { MC210CS }(U N)\end{array}$ & 28 buah & Rp. 16.100 .000 \\
\hline 2 & Konektor SC & 28 buah & Rp. 532.000 \\
\hline 3 & Kabel Serat Optik & $\begin{array}{l}6.831 \\
\text { meter }\end{array}$ & Rp. 321.330.240 \\
\hline 4 & Gigabit Switch & 1 buah & Rp. 890.000 \\
\hline \multicolumn{3}{|c|}{ Total Biaya } & Rp. 338.852.240 \\
\hline
\end{tabular}

Tabel 9. Perangkat Jaringan GPON

\begin{tabular}{|c|l|c|c|}
\hline No & Nama Perangkat & Jumlah & Total Harga \\
\hline 1 & $\begin{array}{l}\text { ZTE OLT C320 16 } \\
\text { Port GPON }\end{array}$ & 1 buah & Rp. 31.900.000 \\
\hline 2 & $\begin{array}{l}\text { GPON ONT F660 } \\
\text { ZTE }\end{array}$ & 77 buah & Rp. 191.656.080 \\
\hline 3 & $\begin{array}{l}\text { Splitter PLC Fiber } \\
\text { Optic SC APC 1 to 8 } \\
\text { Core (1 SC to 8 SC) } \\
\text { Fiber Optik }\end{array}$ & 11 buah & Rp. 2.200.000 \\
\hline 4 & $\begin{array}{l}\text { ODP Tiang PAZ 8 } \\
\text { Core lengkap tanpa } \\
\text { Pigtail }\end{array}$ & 11 buah & Rp. 4.950.000 \\
\hline 5 & $\begin{array}{l}\text { Kabel Fiber Optik } \\
\text { Single Mode 8 Core } \\
\text { Netviel }\end{array}$ & $\begin{array}{l}3.020 \\
\text { meter }\end{array}$ & Rp. 82.114.000 \\
\hline 6 & $\begin{array}{l}\text { FIBER OPTIC } \\
\text { DROP CABLE 1 } \\
\text { CORE }\end{array}$ & 1 reel & Rp. 3.340.260 \\
\hline 7 & Konektor SC & 176 & Rp. 3.344.000 \\
\hline \multicolumn{3}{|c|}{ Total Biaya } & Rp. 319.504.340 \\
\hline
\end{tabular}

Tabel 8 dan 9 menunjukkan bahwa jaringan GPON memerlukan jumlah perangkat yang lebih banyak dan biaya yang lebih besar dibandingkan dengan jaringan eksisting. Namun jika dalam kondisi yang sama untuk memenuhi komunikasi ke setiap gedung dengan asumsi jaringan eksisting baru memenuhi $20 \%$ komunikasi optik ke gedung yang ada. Sehingga estimasi biaya jaringan eksisting dapat dikalikan 5 untuk mendapatkan $100 \%$ transmisi optik dan menghasilkan biaya sebesar Rp. 1.694.261.200. Sehingga estimasi biaya model jaringan eksisting jauh lebih besar dari jaringan GPON yang hanya sebesar Rp. 319.504.340. Untuk itu, komunikasi optik dengan teknologi GPON dapat digunakan untuk pemerataan jaringan optik ke seluruh gedung produktif yang ada di kampus Universitas Udayana Bukit Jimbaran dengan keterbatasan 22 core. Sesuai dengan hasil perancangan kelayakan jaringan GPON yang dirancang masih jauh dari margin atau standar yang ada. Sehingga model jaringan GPON ini layak dipertimbangkan sebagai model pengembangan jaringan serat optik yang ada di kampus Universitas Udayana Bukit Jimbaran dalam pemerataan komunikasi optik ke seluruh gedung produktif yang ada.

\section{KESIMPULAN}

Dalam penelitian ini telah dipaparkan kondisi jaringan optik eksisting kampus Universitas Udayana Bukit Jimbaran menggunakan model jaringan point to point dengan menggunakan 2 buah core untuk setiap transmisi. Pada saat ini baru 18,2\% dari 77 gedung yang menerima transmisi optik. Berdasarkan parameter link power budget terkecil sebesar $16,514 \mathrm{~dB}$, rise time budget sebesar $0,275 \mathrm{~ns}$, dan BER terbesar yaitu 1.98 $x$ 10-117 masih sangat baik dibandingkan standar yang ada dan layak dikembangkan ke jaringan GPON untuk memenuhi komunikasi optik ke seluruh gedung dengan jumlah core yang terbatas.

Jaringan GPON yang dirancang dapat memenuhi komunikasi ke semua gedung yang ada dengan menggunakan 22 core serat optik. Dengan desain ini dapat dilihat bahwa parameter link power budget, rise time budget, dan BER memenuhi standar yang ada yaitu untuk link power budget terkecil lebih dari 0 yaitu $12,04 \mathrm{~dB}$, rise time budget lebih rendah dari $0,7 \mathrm{~ns}$, yaitu $0,28 \mathrm{~ns}$, dan BER terbesar lebih rendah dari $10^{-9}$, yaitu $2,32 \times 10^{-102}$.

Pemanfaatan jaringan GPON dapat menghemat penggunaan core menuju ke pusat layanan dengan kebutuhan perangkat yang lebih sedikit dan biaya yang lebih murah. Kondisi 
jaringan eksisting melayani 14 gedung dengan menggunakan 28 core. Jika terlayani $100 \%$ menggunakan model point to point maka akan diperlukan 154 core untuk memenuhi komunikasi ke 77 gedung yang ada. Pengembangan jaringan menggunakan teknologi GPON hanya memerlukan 22 core. Sehingga jaringan GPON lebih sederhana dan ekonomis untuk pemenuhan komunikasi optik ke seluruh gedung yang ada di kampus Universitas Udayana Bukit Jimbaran.

\section{DAFTAR PUSTAKA}

[1] 2016. The Udayana Website. Available: https://www.unud.ac.id/in/tentangunud17-Sejarah-UniversitasUdayana.html. Diakses tanggal 20 Oktober 2017

[2] 2018. The Ayokuliah Website. https://ayokuliah.id/universitas/universit as-udayana/. Diakses tanggal 20 Oktober 2017

[3] 2018. The Wikipedia Website. https://id.wikipedia.org/wiki/Universitas Udayana. Diakses tanggal 21 Oktober 2017

[4] Ignita Gita.D.P, Sugito, S.Si.,MT and Ageak Raporte Bermano, S.T. "Perancangan Jaringan Akses Fiber To The Home (FTTH) dengan Teknologi Gigabit Passive Optical Network (GPON) di Private Village, Cikoneng". e-Proceeding of Engineering : Vol.2, No. 3 Desember 2015

[5] Waldi Saputra Harahap and M Zulfin. "Analisis Karakteristik Serat Optik Single Mode "NDSF (Non Dispersion Shifted Fiber)" dan "Nzdsf (Non Zero Dispersion Shifted Fiber)" Terhadap Kinerja Sistem Dwdm". Singuda Ensikom. vol. 11, no. 29/April 2015

[6] Ismail Faruqi and Sihar P Panjaitan. "Studi Perancangan Jaringan Akses Fiber To The Home (FTTH) dengan Menggunakan Teknologi Gigabit Passive Optical Network (GPON) di Perumahan CBD Polonia Medan". Singuda Ensikom. vol. 6, no. 1/Januari 2014

[7] Imam Rafif Hanif, Sugito, S.SI., M.T., and Putu Yasa, S.T., MT. "Perancangan Jaringan Akses Fiber To The Home (FTTH) Dengan Teknologi Gigabit Passive Optical Network
(GPON) Di Perumahan Bumi Adipura, Cluster Cempaka". e-Proceeding of Engineering : Vol.4, No. 2 Agustus 2017

[8] Yus Natali and Retno Dwihapsari. "Perancangan Kapasitas Jaringan Fiber To The Home (FTTH) pada Perumahan Tawanganom Magetan Menggunakan Optisystem". Jurnal ICT Penelitian dan Penerapan Teknologi. vol. 7, no. 132016

[9] Ravneet Kaur and Sanjeev Dewra. "A Review on Passive Optical Network". International Journal of Innovative Research in Computer and Communication Engineering. vol.3, Issue 4, April 2015

[10] Sumanpreet and Sanjeev Dewra. "Performance Analysis of Gigabit Passive Optical Network Using 2Gbit/Sec Downstream Transmission". International Journal of Innovative Research in Computer and Communication Engineering. vol. 4, issue 2, February 2015

[11] Tomas Horvath, Lucas Koci, Michal Jurcik and Miloslav Filka. "Coexistence GPON, NG-PON, and CATV systems". International Journal of Engineering Trends and Technology. vol. 21, no. 2, Marc 2015

[12] 2018. The Optiwave Website. https://optiwave.com/optisystem-

overview/. Diakses tanggal 25 November 2017

[13] Linda Ulifaurrosyidah Purnamasari (2015). "Perancangan dan Analisis Jaringan Fiber To The Home (FTTH) dengan Optisystem untuk Perumahan Permata Sariwangi Asri Gegerkalong Bandung". [Online]. Available

[14] Rian Jefri. "Perancangan Jaringan Akses Fiber To The Home (FTTH) Menggunakan Teknologi Gigabit Passive Optical Network (GPON)". eProceeding of Engineering : Vol.3, No.11 Desember 2016

[15] Winda Friandawa, Ir.Akhad Hambal, M.T, and Afief Dias Pambud, S.T., M.T. "Analisa Kinerja Sistem Komunikasi Optik Jarak Jauh Dengan Teknologi DWDM Dan Penguat (EDFA)". eProceeding of Engineering : Vol.4, No.1 April 2017 